Review Paper

\title{
Status of seawater intrusion in coastal aquifer of Gujarat, India: a review
}

\author{
Swayam Siddha ${ }^{1} \cdot$ Paulami Sahu $^{1}$ (i)
}

Received: 13 June 2020 / Accepted: 14 September 2020 / Published online: 23 September 2020

(c) Springer Nature Switzerland AG 2020

\begin{abstract}
Seawater intrusion (SWI) is a universal concern, intensified and aggravated due to over-exploitation of groundwater, sea-level rise, and climate change in the coastal province. According to the Ghyben-Herzberg principle, the stability between freshwater and saltwater is caused by the density difference between the two, until the pressure equalizes. The keystone of India's geography, economy, biodiversity, and the environment are its extended and vast coastline, which occupies the most precious as well as potential aquifer system. This review mainly fascinated on the status, knowledge, and vulnerability of SWI within the aquifers of the coastal region of Gujarat, India. Foregoing investigations reveal that the meteoric intensification in the salinity of coastal regions of Gujarat is the chief provenance of socioeconomic development and environmental degradation. Different studies are performed to analyze and mitigate the SWI problem. In this region, groundwater over-exploitation is the foremost driver of SWI. There are miscellaneous developmental and management skills and techniques to diminish the SWI in coastal regions of the world. Numerous models are fabricated and established to analyze and epitomize the complications associated with it. Numerical models suggest some valuable techniques to manage groundwater-related problems. This study also delivers some advanced management strategies such as dilution of salinewater by artificial recharge techniques, construction of physical barriers in the subsurface to reduce the intrusion etc. feasible to the coast of Gujarat.
\end{abstract}

Keywords Seawater intrusion · Ghyben-Herzberg principle · Salinity contamination · Gujarat · Artificial recharge

\section{Introduction}

On the planet earth, groundwater is the enormous source of freshwater. It has been utilized to a great extent to meet the demands of agricultural, industrial, and municipal water supply schemes all over the world including coastal regions [1]. Coastal belts encompass some of the highest densely populated zones with an average population density of almost 80 individuals per sq. $\mathrm{km}$, which is estimated as twice of the world's average population density [2]. Along with rampant increase in the population growth, uninterrupted progress in standards of living is additionally enhanced the groundwater requirement in coastal regions [3]. But seawater intrusion (SWI) in the coastal region is such a menace that not only contaminates this precious groundwater resource but also affects vegetation, soil conditions and the sustainability of groundwater that contributes to the economic improvement of the coastal communities. Therefore, SWI is considered as a global coastal threat. Furthermore, the key elements contributing to SWI comprise changes in land use patterns which might influence the recharge of aquifer and rise in sea-level owing to climate changes. Degradation of groundwater quality is influenced by the intrusion of seawater into the coastal aquifers where less than $1 \%$ of

Paulami Sahu, paulamisahu@gmail.com; Swayam Siddha, swayamsiddha.siddhi@gmail.com | ${ }^{1}$ School of Environment and Sustainable Development, Central University of Gujarat, Sector-30, Gandhinagar, Gujarat 382030, India. 
seawater can transform drinkable freshwater to unsuitable for the same [4].

SWI has been defined as the flow of water towards the land from the sea into the adjoining inland aquifer system [4]. Foregoing research and investigations have acknowledged two basic categories of SWI: (i) active and (ii) passive [5-7]. In the active SWI, the hydraulic gradients tilt in the direction of the land, and strengths originated by the disparities in densities and crude groundwater movement proceed within the similar direction, initiating additional insistent salinization [7], whereas the hydraulic gradient angles in the direction towards the sea in case of passive SWI. This phenomenon evaluates the density-induced strengths which are operating within the reverse track of the natural movement of groundwater, generating symmetrical and wedge-shaped plumes of seawater which are conventionally analogous with SWI [8].

The degree of SWI in any coastal region is driven by the geology, presence of palaeo-salinewater, hydraulic gradient, amount of groundwater extraction, rock-water interaction, recharge of groundwater and anthropogenic contamination [9]. The intensity of SWI differs extensively from regional to the global scale. Therefore, numerous studies have been conducted in coastal zones throughout the world to understand the vulnerability and the effect of SWI. Various geophysical and geochemical studies in addition to experiments carried out in the laboratory. Techniques related to hydrodynamic, and modeling are often integrated with multivariate geostatistical analysis, geospatial analysis, and tracer studies have been adopted for investigation $[6,7]$. The considerable difference in resistivity between the saturated formation of the saltwater and the freshwater has been applied by numerous researchers for investigating the SWI in coastal areas [10]. Groundwater salinity was estimated in the western part of the Netherlands using the resistivity method [11]. The results of the resistivities were interpreted which found to be strongly interrelated to the analytically computed salinity of groundwater. Similarly, the Schlumberger sounding resistivity method is a potent technique for delineating the saltwater-freshwater interface. This tool was applied in the geological setting of the eastern shore of Virginia, and SWI zone was mapped for the region [12]. The hydrogeochemical and isotopic investigations have been carried out globally to evaluate the quality of groundwater and to identify the hydrological and salinization processes in various coastal aquifer systems $[13,14]$. Integration of stable isotopes $\left(\delta^{18} \mathrm{O}\right.$ and $\left.\delta^{2} \mathrm{H}\right)$ along with major ionic ratios of groundwater have been employed in both the shallow and deeper aquifers to study the mechanisms of SWI $[15,16]$.

The ruin of environment that emerging from SWI is generally related to the relevance of excessive groundwater salinity into cultivation, following reformed soil chemistry and depleted soil productivity $[17,18]$. The key losses that take place in the world due to salinity impacts on groundwater and other freshwater resources include amplification in energy cost due to deepening of water levels to achieve drinkable water, agricultural losses, losses of domestic customers who have to shift to another water source, irreversible loss of the aquifer as a safe store for freshwater, increased water scarcity and meager public health [19].

Globally, India is the greatest consumer of groundwater extracting $230 \times 10^{9} \mathrm{~m}^{3}$ of water/year and having $25 \%$ of the population resides in the coastal belts $[20,21]$. Ambiguity in rainfall, shortage of surface water in Summer season, at a few areas and the onsite accessibility of clean groundwater have brought about greater dependency on groundwater resources in India. Groundwater overextraction in urban areas of coastal belts must show the way to SWI in numerous locations. Various researches have focused on a reduction in the level of groundwater and decline of fresh groundwater resources in India [22, 23]. Their studies reveal that the semi-arid state, Gujarat having the longest coastline among the Indian States, is critically affected by salinity contamination [24, 25]. Therefore, the key objectives of this review are to identify the status of SWI in coastal regions of Gujarat, represent the lacuna of scientific research and identify possible efficient management plans suitable to combat SWI in Gujarat.

\section{Seawater intrusion (SWI)}

SWI is predominantly triggered by over-stressing the groundwater resources of the coastal zones owing to the over-population, urban sprawl, industrial expansion, and numerous developmental activities. The degree of SWI is expected to associate with the climate change effects like an increase in sea-level and rise of temperature and reduction of precipitation, coupled with excess groundwater abstraction. The origin of SWI is wide-ranging, for example, over-withdrawal and the variation between the densities of seawater and freshwater [26]. The manifestation of SWI owing to over-exploitation of groundwater detectable within the coastal regions because of a decline in groundwater levels [27]. The principle of static equilibrium between both freshwater and salinewater is commonly renowned as the Ghyben-Herzberg principle. This principle was applied to hydrologic issues of seacoasts by W. Badon Ghyben, a Dutch captain of engineers, in 1889 and Herzberg (1901) [28, 29]. Numerous factors disturbing the hydrodynamic equilibrium between the freshwater and seawater causing SWI in coastal aquifers are geological factors such as lithology, geomorphology and 
structural features, tidal activities, climate change and rise in sea-level and anthropogenic interferences.

\section{Water budget}

Water takes various forms in its existence like vapor in atmosphere, water, snow, or ice on the surface and as groundwater capturing the entire voids within the stratum of geology underneath the surface [30]. Entire supply of water into the earth is always in continuous movement from earth to atmosphere and vice versa excluding the subterranean groundwater. This structure of circulation of water is renowned as hydrologic cycle. This cycle is incredibly enormous and intricate having a bulky quantity of pathways with fluctuating period [31]. Key elements of hydrological cycle are precipitation $(P)$, alteration of terrestrial storage of water ( $\triangle T$ TWS) with both subsurface and surface storage runoff $(\mathrm{Q})$ that envelope infiltration, baseflow also surface runoff and evapotranspiration (ET) those are valuable in assessing the equation of water budget for any basin.

Commonly, water budget equation can be given as [30]:

$P-\mathrm{ET}-Q \pm \Delta \mathrm{TWS}$

Water budgets furnish methods for evaluation of accessibility and sustainability of the water supply. The water budget basically enunciates that the change in rate of stored water in a region, like a watershed, is balanced by the flow rate of water into and out of that region. The indulgence of water budgets and primary hydrologic processes affords a core for effective resource of water with proper environmental planning and management [30]. For evaluating the consequences of changing climate and anthropogenic events on water resources, the modifications are perceived in water budgets of any region over a period can be measured. The effects of numerous factors like geology, land use, soil, and vegetation on the hydrologic cycle of different regions can be calculated. Water budgets deliver a foundation for valuation by means of a natural or anthropogenic alteration in a single portion of the hydrologic cycle possibly will distress the other features of the cycle [30].

Therefore, the equation of water budget states that [30]:

$$
\text { Change in Storage }=\text { In Flow }- \text { Out Flow }
$$

The infiltration of water into the soil moves to the unsaturated zone $\left(\Delta S_{u}\right)$ and recharges the groundwater $\left(\Delta S_{g w}\right)$ [32]. Groundwater $\left(R_{\mathrm{gw}}\right)$ and water of the unsaturated zone $\left(R_{\text {sub }}\right)$ can also provide input to the river as subsurface runoff. The runoff process comprises three elements like (a) the overland flow, (b) the interflow, and (c) the baseflow.
The overland flow is also known as surface runoff $\left(R_{\mathrm{s}}\right)$ or Hortonian overland flow. The interflow (or subsurface runoff $R_{\text {sub }}$ ) is the part of infiltrated rainfall that flows laterally across the upper soil layers until it achieves the stream channel. The baseflow (or groundwater runoff, $R_{\mathrm{gw}}$ ) is the section of infiltrated rainfall that reaches the groundwater table and then discharges into the streams [32, 33]. The direct runoff integrated with the baseflow runoff provides to the total discharge (or streamflow). These elements and their inter-relations lead to the following formulation of equation [34]:

$P=R_{\mathrm{S}}+R_{\text {sub }}+R_{\mathrm{gw}}+E_{\mathrm{s}}+E_{\mathrm{i}}+E_{\mathrm{t}} \pm \Delta S$

where $P=$ precipitation $\left[\mathrm{hm}^{3} /\right.$ time unit]; $R=$ runoff (s: surface, sub: subsurface, gw: groundwater) $\left[\mathrm{hm}^{3} /\right.$ time unit]; $E=$ Evaporation (s: surface, i: interception, $\mathrm{t}$ : transpiration) $\left[\mathrm{hm}^{3} /\right.$ time unit] $; S=$ Change in storage over time $\left[\mathrm{hm}^{3} /\right.$ time unit]; $1 \mathrm{hm}^{3}=1$ million $\mathrm{m}^{3}$.

The movement of groundwater is along the flow paths of fluctuating lengths from recharge areas to discharge areas. The universal flow paths begin at the water table, persist through the groundwater aquifer system, and terminate at the stream or at the pumped well. The groundwater flow in any section of aquifer is obtained by using transmissivity, the hydraulic gradient, and the area through which the water is moving. The groundwater flow through an aquifer is obtained from the equation [35]:

$Q=T \times i \times W$

where $Q=$ total groundwater flow through the section considered; $T=$ average transmissivity in that section; $i=$ hydraulic gradient; $W=$ the width of the section being considered.

Humans alter the natural or pre-development flow system by withdrawing (pumping) groundwater for usage, transforming patterns of recharge by irrigation and urban development, altering the vegetation types, and other anthropogenic activities. The source of water for pumpage is supplied by (1) increased recharge of groundwater aquifer system, (2) decreased discharge, (3) removal of water that was stored in the system, or some combination of these three. Thus, the groundwater system serves both as a water reservoir and a water-distribution system [36].

\section{Seawater intrusion: world scenario}

SWI into coastal aquifers is recognized as a single possible footprint of recent climate change [37]. Throughout the twentieth century, the global mean sea-level (GMSL) amplified with a typical rate of $1.8 \mathrm{~mm} /$ year [38]. The rise in sea-level creates magnified pressure in coastal aquifers 
enduring inundation of land and reduction in riverine residue yield to estuaries [39]. The concern of such an enhancement in the sea-level is to intensify SWI into the coastal aquifers. The influences of unstable circumstances like sea-level and land use, during the Holocene on SWI in a 2-dimensional intersect at the Dutch coastline were assumed [40]. The development of salinization in considerable coastal aquifer systems, like Zona Citricola (Mexico), Laizhou Bay (China), Fortescue Marsh (Australia), Rhone Delta (France), Buan-gun (Korea), Saturna Island (Canada), and Shean-Harod (Israel) have been probed globally by different scientists and researchers $[9,13,14,41]$. Numerous works in Atlantic Canada have indicated the occurrence of SWI [42]. SWI was exposed to have emerged at Shippagan (NE New Brunswick) and Richibucto (SE New Brunswick), where over-pumping is the liable reason [43]. Seawater intrusion was also detected at Upper Lawrence town and Summerside, where low freshwater head evolved in land-ward alter of the saltwater-freshwater edge with lessening or redeployment of withdrawing was consequently suggested $[44,45]$. Due to the expansion of huge groundwater demand, intrusion has also been recognized at Pictou. In Prince Edward Island, saltwater intrusion seems to be arisen primarily owing to consequence of natural circumstances and even in areas with insignificant pumping $[46,47]$.

In several countries, like Cyprus, Israel, Mexico, and Oman, numerous dug wells all along the coastline have had to be ceased due to SWI [48]. In California, salinewater from the Pacific Ocean has percolated into the coastal aquifer of Los Angeles Basin [49]. In these areas ever-increasing exploitation of the groundwater causes lowering of groundwater tables and caused SWI into the aquifers. These countries are facing a scarcity of adequate drinking water and either looked for substitute sources, such as imported water, or implemented expensive scientific solutions, such as desalination technology.

Owing to excruciating anthropic exercise because of urbanization and proliferation of tourism with an approximate growth rate of 0.1 million guests/year that affects the coastal hydrologic systems the coastal regions of Phuket Island confront the jeopardy of SWI [10]. Geo-electrical surveys of four lines were prosperously operated in the field of study in this research. High resolution subsurface resistivity irregularity of seawater intrusion is shown by two-dimensional (2D) inversion models from the resistivity data. With the objective to know the history of a saltwater affected groundwater system and its presumably response to historic and future changes a study was accomplished in the Danish-German border neighboring the Wadden Sea [50]. In this study, integrated hydrogeological, geophysical, and geochemical data with a numerical density dependent groundwater flow and transport model were used. Airborne electromagnetic data exhibiting saltwater up to $20 \mathrm{~km}$ inland is competently compared with the stretch of the resembled SWI. The results explain the saltwater originating from a combination of laterally intruding seawater and vertically infiltrating transgression water.

More than $50 \%$ of population in Africa reside in coastal areas with the demand of freshwater as a basic human need in the limelight [51]. The coastal strip hydrosystems with $38 \%$ of the African coast is vigorously distressed by human developments and is assorted by the United Nations Environment Programme (UNEP) in 1998 as under arduous menace due to over-development [52]. Because of lofty permeability and lower hydraulic gradient arising from huge principal porosity and minor karstification, salinity pollution is enormously noticeable in regions with coral limestone. Amongst the most endangered aquifers owing to SWI created by groundwater over-utilization is also located along the Kenyan south coast aquifer system (Tiwi) in East Africa [53]. Utilizing climatic and geophysical data to evaluate the contemporary stretch, previous development and drivers of coastal aquifer salinization was studied [54]. Local aquifer lithology, groundwater abstraction and freshwater recharge in floodplains control SWI spatial designs which are revealed by geophysical data. Over the past 30 years the saltwater front has proceeded towards the well-field by as far as $2 \mathrm{~km}$ and rose by as high as $80 \mathrm{~m}$ that reciprocates with a maximal velocity of about $60 \mathrm{~m} /$ year horizontally and $2 \mathrm{~m} /$ year vertically which is shown by comparison with previous (1984) resistivity data. A study on SWI in Port Sudan in 2015 reveals that the interface between the fresh and brackish water is about $8 \mathrm{~km}$ from the coast but off the coastline it is about $2 \mathrm{~km}[55]$.

Likewise, because of stress affiliated with increased demand of water and climate change, SWI has been featured as a hazard to Australia's coastal aquifers in all states and the Northern Territory [56]. The zones of highest risk to SWI in unconfined aquifers at Derby, West Australia (WA) and Esperance (WA) as well as confined ones at Esperance (WA) and Adelaide, South Australia (SA) are spotted through the physically based, analytic method [57]. This method gives information on the expanse of seawater in aquifers and the alteration from passive to active SWI, where active SWI concludes about the inland movement of the interface under a land-ward sloping hydraulic gradient $[58,59]$.

A model is a basic illustration of the complex natural world. An infrastructure to synthesize information of the field and conceptualize hydrological processes quantitatively is bestowed by a model of groundwater. These models have significant roles concerning both development and management of the groundwater resources, and in forecasting the consequences of management measures. 
Owing to rapid expansion of computation technology, spacious accessibility and accessibility of numerous modeling software, the modeling of groundwater has turned a worthy tool for specialized hydrogeologists for efficient execution of majority tasks [60].

The coastal aquifers management needs cautious developmental schemes of extraction procedures to conquer SWI. In coastal aquifer, the prediction and control of saltwater circulation may be achievable by integrating different types of models. With the advancement of computer technology and proficient numerical codes, numerous case studies on SWI have been presented worldwide applying 3D numerical models [61]. There has been increasing curiosity in exploring the dilemma of inland boundary conditions and SWI due to rise in sea-level, which have a considerable impact in recent times [62]. A FVCOM-based numerical model was built to analyze the seasonal changeability of currents and salinity in the Indus River Estuary, Pakistan [63]. The model was thoroughly calibrated with monitored data of water level, current velocity and salinity. Similarly, a FEFLOW model was created to scrutinize the collective paraphernalia of over-abstraction and SWI in the Pingtung Plain coastal aquifer system, Taiwan [64]. The model was created in distinctive layers to signify the three aquifers and two aquitards.

\subsection{Saltwater intrusion meetings (SWIMs)}

The Saltwater Intrusion Meetings (SWIMs) are a sequence of conferences/meetings that has been organized all over the world, in various countries on a two-yearly basis since 1968. The primary aim of SWIMs is to integrate the people for acquiring advanced technological knowledge about innovative discoveries and exchange knowledge of SWI in groundwater systems [65]. The first benefaction of SWIM about the use of numerical techniques was done by Verruijt (1972) [66]. He illustrated the principles of the finite element method and exhibited two applications regarding theoretical problems of freshwater-saltwater interface. A handful of SWIM benefactions contend with (1) the flow of saline groundwater in inland aquifers like the genesis and migration of brines originating from leaching of salt domes or stratiform salt deposits [67]; and (2) the presence of brackish and saline groundwater due to aridity [68]. In Husum, Germany, in the year 2014, the number of participants in SWIM has the apex at 165 over the years. The fifth SWIM arranged in a Baltic country from 17th to 22nd June 2018 is the 25th SWIM in Gdańsk, Poland. Considering the methods of all technical and managerial execution to protect and restore the water bodies and the environment as well the scope of SWIM changed successively and extended a great deal from sheer over-use of coastal and continental aquifers which may be influenced by saltwater to all the facets of a sustainable development of groundwater resources. During early 2000s, to label SWI at the global scale SWICA (Saltwater Intrusion in Coastal Aquifers) was established and an enterprise created. In the year 2001, Essaouira, Morocco, the first SWICA meeting was held, and in the year 2003 the second event was conducted in Merida, Mexico. In the year 2006, a joint SWIM-SWICA conference was scheduled in Cagliari, Italy. To amalgamate both the groups as SWIM and to schedule a conference every 2 years was decided in this first joint meeting. The first Asia-Pacific Coastal Aquifer Management Meeting (APCAMM) was held in 2009. Having similar objectives as the SWIM, this conference has a specific geographic focus. In the year 2016, SWIM and APCAMM were organized jointly in Cairns.

\section{Seawater intrusion: Indian scenario}

The Indian coastline is having around $7500 \mathrm{~km}$ extent, including the coastline of mainland of $5400 \mathrm{~km}$. Almost $25 \%$ of entire residents of India inhabits into the coastal belts of the country and there is an incessant urban sprawl in the coastal regions. Figure 1 represents major coastal states affected by seawater and SWI studies conducted in various parts of coastal India. Many of the coastal dwellers are dependent of groundwater to meet their daily needs. Therefore, there is a requirement for the sensible utilization of groundwater in such regions [69]. According to report of integrated coastal zone management project (ICZMP) almost 250 million communities reside within $50 \mathrm{~km}$ from the shoreline of India [70]. Consequently, the environmental amenity of oceanic and coastal ecosystems of India plays an essential responsibility in India's economic development. The coastal province of India bestows a diversity of geomorphological segments and landforms evolved during numerous aspects like marine and aeolian actions, different category of rock, atmospheric, climatic and the fluvial impacts, tectonics, land cover and different categories of topography. The state wise division of coastline length and characteristic features are provided in Table 1 [71].

Distinguishable mechanisms are responsible for SWI in coastal territory of India. Earlier reported mechanisms proclaim that SWI owing to excessive exploitation of groundwater [72].

A strong opinion arises from most of the researchers is as follows: chloride symbolizes as an archetypical tracer of SWI and in perceiving a difference in active intrusion from freshwater flushing. Also, it assists in interpreting the relationships involving brackish water entities, adjoining freshwater within coastal sandstone along with carbonate aquifers [73]. Multitudinous studies also probe into the 


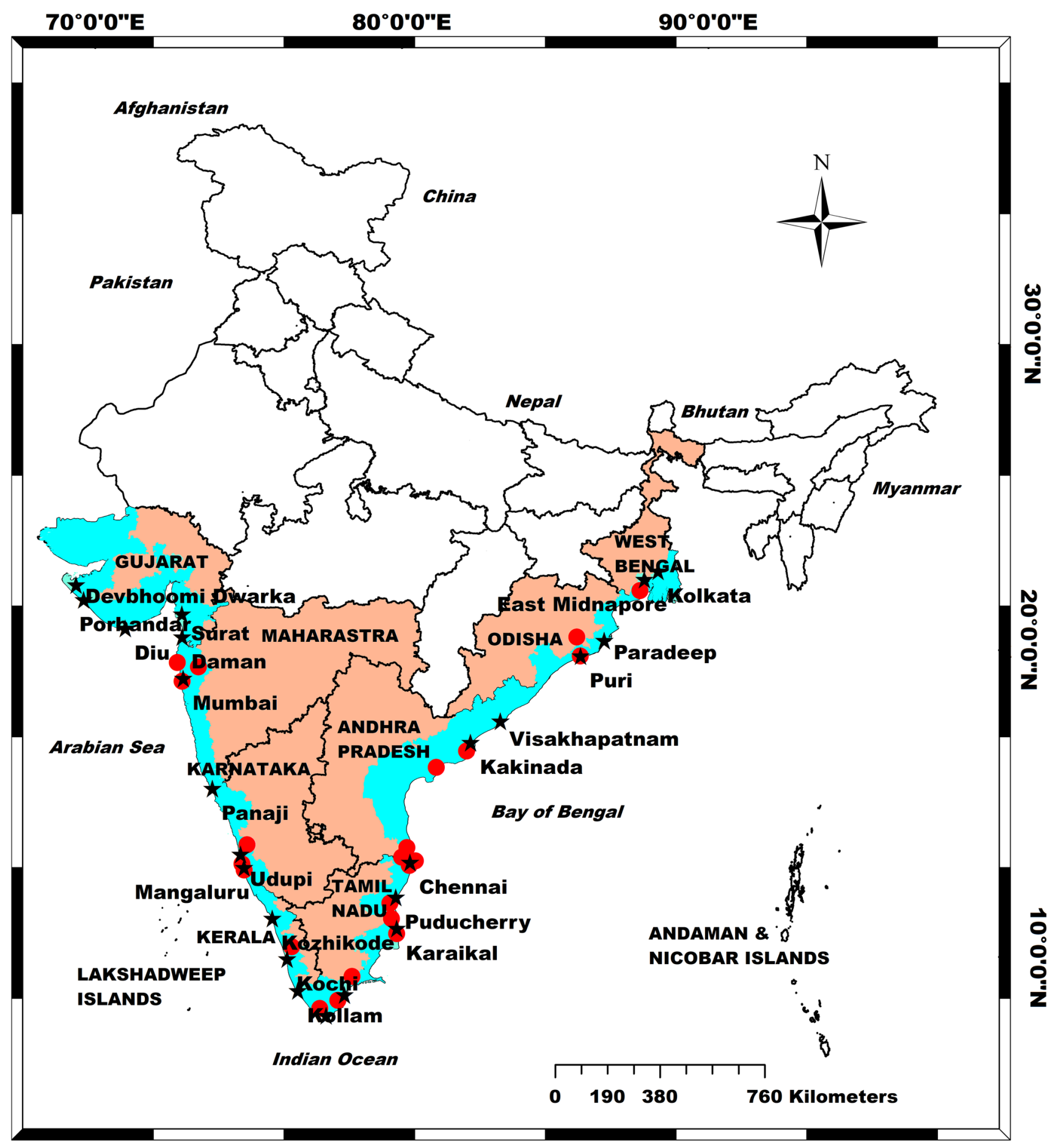

\section{LEGEND}

Seawater Intrusion Studies

$\downarrow$ Major Coastal Cities of India

\section{Coastal Districts of India}

Coastal Districts under the influence of Seawater

Fig. 1 Seawater influenced Coastal states and SWI studies in India 


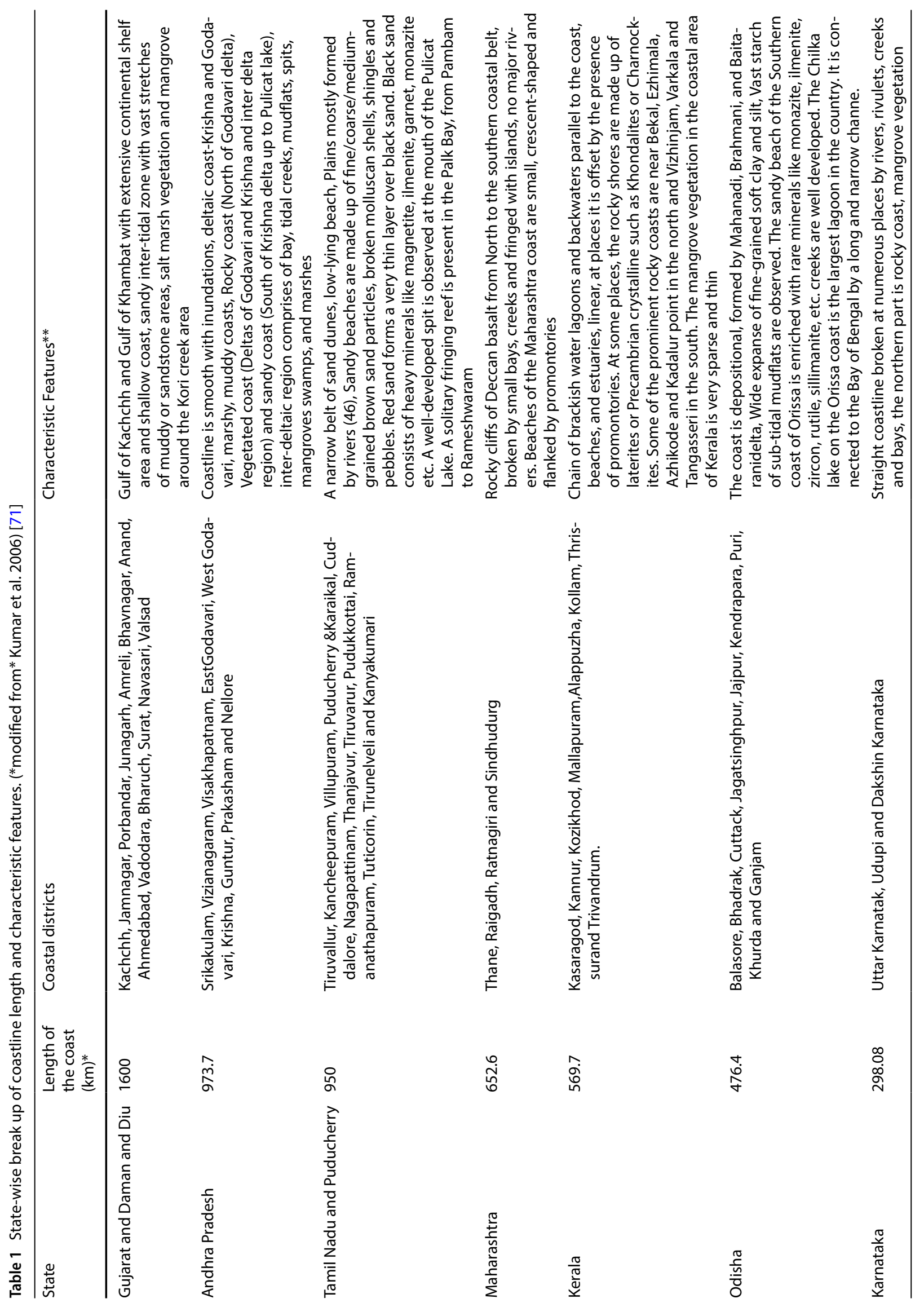


inevitable circumstances of SWI and endeavor to acknowledge the freshwater-seawater edge through analytical and hydrochemical techniques [4]. Kumar et al. (2015), premeditated the SWI in a shallow aquifer of Periyar River Basin, Kerala [74]. The results of the resistivity study indicate that the clay horizons with excessive salinity. SWI and anthropogenic activities like salt panning were assessed in Thamirabarani delta of Tamil Nadu [75]. The engineering management plan like construction of weir across the Thamirabarani River near Mukkani village has been projected. By introducing this plan, the freshwater of the river can be deflected to the salinity contamination and seawater invaded regions to convalesce the circumstances. Geospatial technology-based seawater mixing index (SMI) was carried out on Southern India [76]. Bestowing to the final GIS map, maximum portion the region was harshly affected by SWI owing to over-exploitation of groundwater. Major parameters like $\mathrm{Na}^{+}, \mathrm{Cl}^{-}, \mathrm{Mg}^{2+}$, and $\mathrm{SO}_{4}{ }^{2-}$ were considered to prepare the $\mathrm{SMI}$ by using overlay analysis method in GIS platform. Stable isotopic signature $\left({ }^{18} \mathrm{O}\right.$ and ${ }^{2} \mathrm{H}$ ) play an important role to ascertain the derivation in the source of groundwater and intermixing mechanism amongst both the fresh groundwater and the seawater [77]. A stable isotopic $\left(\delta^{18} \mathrm{O}\right.$ and $\left.\delta^{2} \mathrm{H}\right)$ study was conducted in Mahanadi delta, Bay of Bengal, Odisha. Here, the isotopic signature indicates that the intermixing of seawater and fresh groundwater owing to inland intrusion of seawater in this coastal region [16]. Another study was conducted in the coastal region of Puri district, Bay of Bengal, Odisha [78]. This study reveals that the aquifers of this region are subjected to continuous influence of seawater-groundwater mixing. According to various studies, over-exploitation and over-pumping is the primary cause of SWI in the coastal region of West Bengal and therefore various geophysical and geochemical investigations are carried out to identify the SWI [79-82]. In the coastline of Andhra Pradesh, rise in sea-level plays a significant role in enhancing the SWI with deteriorating the quality of groundwater and degrading the agricultural lands [83, 84]. Similarly, a hydrochemical investigation was carried out in Thane district, Maharastra, signifies that the low-lying zones are influenced by the SWI owing to the backwater of the sea through the rivers $[85,86]$. Numerous investigations reveal that, in the coastal belt of Karnataka, SWI is mainly influenced by over-exploitation of groundwater resources and tidal activities [87-89].

SEAWAT modeling has been employed to model the SWI in the Nagapattinam coastal aquifers, Tamil Nadu [90]. According to this model, SWI was primarily owing to ingress of salinewater through over-indulgence of groundwater abstraction. The influence of SWI was established in the southern India by Kanagaraj et al. (2018) [91]. In this study geophysical, geochemical, and stable 
isotope techniques like seawater mixing index (SMI) and base exchange index (BEX) were used to determine the SWI [92]. According to this study, about $201 \mathrm{~km}^{2}$ area is affected by SWI. The coastal region of Thiruvallur district, Tamil Nadu indicates a gradual intensification of SWI due to over-abstraction of fresh groundwater [93]. In this area, in the year 1969, the freshwater-seawater interface has occurred $3 \mathrm{~km}$ away from the coast. According to the Central Groundwater Board (CGWB) it has been found to be shifted to an expanse of $13 \mathrm{~km}$ from the coast [20]. A vulnerability analysis was employed in the coastal aquifers of southern India using GALDIT model [94]. This study reveals that an area of $4.5 \mathrm{~km}^{2}$ (1.58\%) extent over distinctive sites of southwest coast of Kanyakumari district are extremely vulnerable zones to SWI. According to the report of CGWB, the status of salinewater aquifer in the coastal region of India are given in the Table 2.

\section{Seawater intrusion: present scenario of Gujarat}

Gujarat state is located on the western coastal region of India and extended between $20^{\circ} 06^{\prime} 00^{\prime \prime} \mathrm{N}$ to $24^{\circ} 04^{\prime}$ $00^{\prime \prime} \mathrm{N}$ and $68^{\circ} 10^{\prime} 00^{\prime \prime} \mathrm{E}$ to $72^{\circ} 28^{\prime} 00^{\prime \prime}$ E latitudes and longitude respectively (Fig. 2). Having an overall area of $1,96,024 \mathrm{~km}^{2}$, Gujarat is the 9th biggest state in India. Its coastline is $1600 \mathrm{~km}$ long, which is nearly $1 / 3 \mathrm{rd}$ of the entire coastline of India and the longest one of the countries. To the west and southwest Gujarat is delimited by the vast Arabian Sea, by Pakistan to the northwest, Rajasthan to the North, Maharastra to the South and Madhya Pradesh to the east. The coastal belt of $1125 \mathrm{~km}$ stretches from Bhavnagar to Lakhpat borders Saurastra and Kachchh districts of Gujarat. It has overall population of 6.03 crore, almost $4.99 \%$ of entire population of India. The major districts affected by salinity in Gujarat are Ahmedabad, Amreli, Anand, Bharuch, Bhavnagar, Porbandar, Jamnagar, Junagadh, Kachchh, Navsari, and Surat [95].

The Gujarat coast is split up into five zones viz., Rann of Kachchh, the Gulf of Kachchh, the Saurashtra coast, the Gulf of Khambat, and the South Gujarat coast from west to east on the ground of geomorphic features. For major part of the year, the Rann of Kachchh (area about 22,000 km²) continues to be saline desert and during monsoon it turns marshy when it becomes over-loaded partly by river water and partly by that of tidal. The surface is enclosed with a layer of salt and shingle when dry. Except in a few small higher regions with accessibility of some freshwater no vegetation is flourished here. The Great Rann (northern

Table 2 Traces of salinewater in the coastal region of India

\begin{tabular}{|c|c|c|c|c|c|}
\hline Coastal region & Location & $\begin{array}{l}\text { Depth (meters } \\
\text { below ground } \\
\text { level) }\end{array}$ & $\begin{array}{l}\text { Electrical con- } \\
\text { ductivity }(\mu \mathrm{S} / \\
\mathrm{cm})\end{array}$ & $\begin{array}{l}\text { Total dis- } \\
\text { solved solid } \\
\text { (ppm) }\end{array}$ & Chloride (ppm) \\
\hline \multicolumn{6}{|l|}{ East Coast } \\
\hline \multirow[t]{2}{*}{ Tamil Nadu and Puducherry } & $\begin{array}{l}\text { Bhuvanagiri- Chidambaram- Porto Novo } \\
\text { belt, south of Tranquebar (Tharangam- } \\
\text { badi) up to south of Nagapattinam } \\
\text { district including Karaikal region }\end{array}$ & $100-300$ & & 30,000 & \\
\hline & Tiruvallur and Tuticorin districts & $4-200$ & $11,000-1,36,800$ & & $4000-74,000$ \\
\hline Andhra Pradesh & $\begin{array}{l}\text { Peddada, Amalapuram, Dangeru, } \\
\text { Cheyyeru and Peddagadimoga in East } \\
\text { Godavari district }\end{array}$ & $94-300$ & & & $>600$ \\
\hline Odisha & $\begin{array}{l}\text { Balasore, Bhadrak, Jajpur, Kendrapara, } \\
\text { Jagatsinghpur, Cuttack, Puri and } \\
\text { Khurda. }\end{array}$ & $98-110$ & & & 17,573 \\
\hline \multirow[t]{3}{*}{ West Bengal } & South of Behala-Sonarpur-Bhangar area & 150 & $5960-41,350$ & & $1750-6300$ \\
\hline & Southern part of Haora district & 160 & 6830 & & \\
\hline & Haldia-Digha coastal tract & $40-60$ & $9000-26,000$ & & \\
\hline \multicolumn{6}{|l|}{ West Coast } \\
\hline Kerala & $\begin{array}{l}\text { Chellanum in Ernakulam district and } \\
\text { Azhikode in Thrissur district }\end{array}$ & 40-60 (Shallow) & 3000 & & \\
\hline Karnataka and Goa & $\begin{array}{l}\text { Hangarkatta in Kundapura block of } \\
\text { Udipi district }\end{array}$ & Shallow & 4230 & & 980 \\
\hline Maharashtra & Thane and Raigarh districts & Shallow & $>2250$ & & \\
\hline Gujarat & $\begin{array}{l}\text { Bhavnagar, Una, Madhavpur, Maliya, } \\
\text { Lakhpat, Surat, Bharuch, Vadodra, } \\
\text { Kachchh districts }\end{array}$ & $30-200$ & $>2250$ & $>2000$ & \\
\hline
\end{tabular}




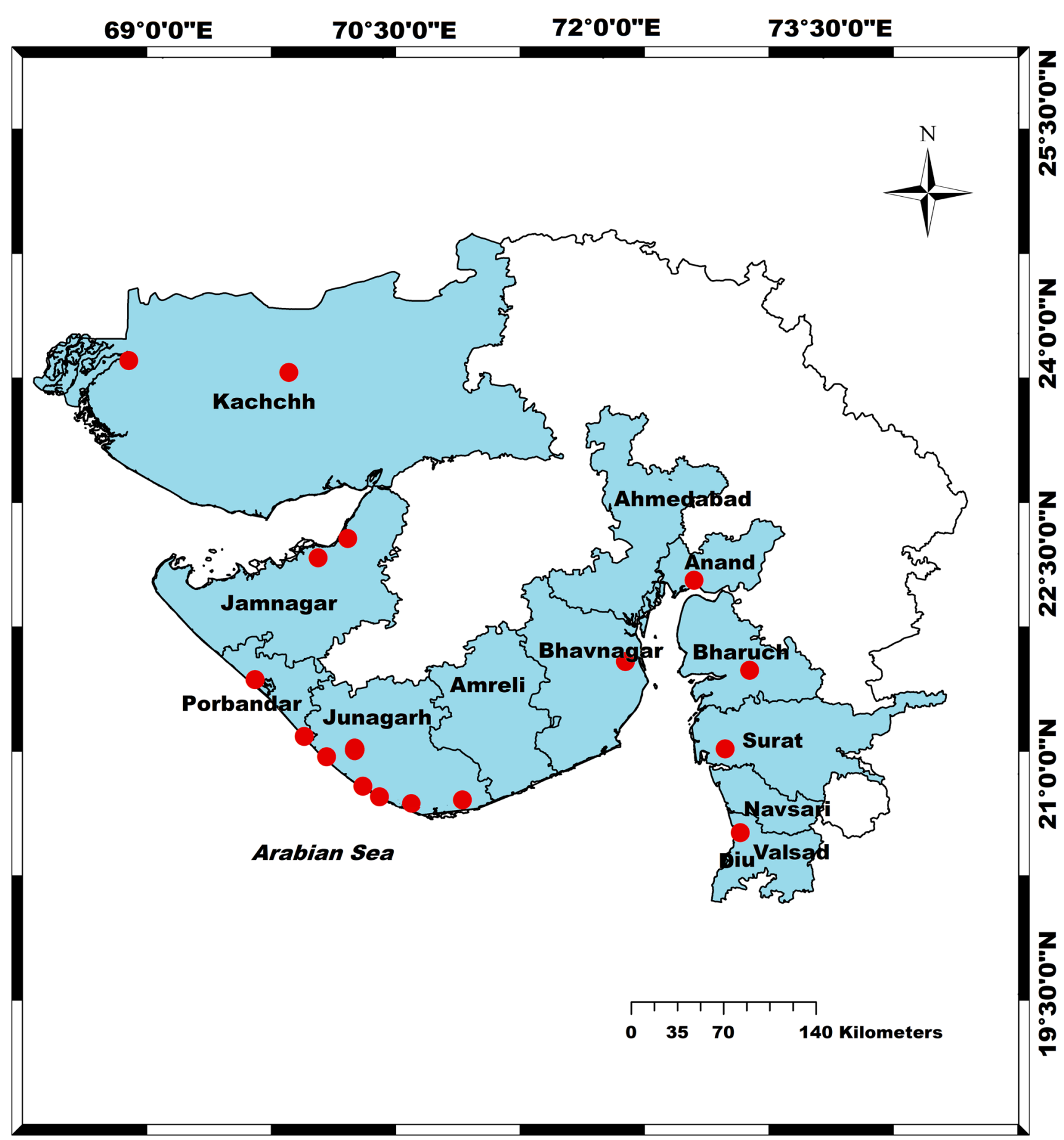

\section{LEGEND}

\section{Seawater Intrusion Studies}

\section{Coasta districts of gujarat under the influence of seawater}

Fig. 2 Seawater influenced Coastal districts and SWI studies in Gujarat 
parts of Rann) and the Little Rann (eastern parts of Rann) are the additional splitting of the Rann. The lower Indus deltaic plain featured with tidal creeks and mangroves lies on the west of the Great Rann of Kachchh. In the Gulf of Kachchh the coastline has substantial mudflats and it is extremely indented with several rocky islands. The coast is braided by coral reefs and mangroves here. Algae, salt marsh, dunes, and salt pans also are very common [96].

The Saurashtra coast has numerous cliffs, islands, tidal flats, estuaries, embayment, coastal depressions or low-lying areas locally termed as 'Ghed', sandy beaches, dunes, spits, bars, bays, marshes, and also upright beaches at some places in Peninsular Gujarat. In Gulf of Khambat, the coast is indented by estuaries and consists of mudflats, dunes, and beaches. The coast of south Gujarat is relatively invariable and indented by a series of creeks, estuaries, marshes, and mudflats. From Great Rann to south Gujarat coast, the coast of Gujarat gives out confirmation for both emergent and submergent coasts $[95,96]$.

\subsection{Hydrogeology of Gujarat}

The diverse terrain conditions have given rise to different groundwater situations in the state. The rock formations ranging in age from Archaean to recent include gneisses, schists, phyllites, intrusive, medium to coarse grained sandstones, basalts, and recent alluvium [95]. A generalized geological map of the Gujarat illustrating primary geological formations is given in Fig. 3. The high relief area in the eastern and north eastern part occupied by Archaean and Deccan Trap have steep gradient allowing high runoff and therefore, have little groundwater potential. The yield of wells in these formations range from 5 to $10 \mathrm{~m}^{3} / \mathrm{h}$ where the yield in sandstones varies from 50 to $170 \mathrm{~m}^{3} / \mathrm{h}$ and in wells tapping quaternary alluvium in Cambay basin ranges between 75 and $150 \mathrm{~m}^{3} / \mathrm{h}$. The top aquifer among the five major ones in alluvial sediments has dried up due to excess withdrawal $[95,96]$. A miscellany of hard and fissured formations incorporating basalt and consolidated sedimentary formations beside semiconsolidated sediments engrosses virtually the whole Saurastra and Kachchh areas advancing the low-lying coastal zones. Moderate yield potential is obtained from the discontinuous aquifers brought about by the rocks with compact and fissured character and an aquifer originated by the friable semi-consolidated sandstone. In the state of Gujarat, the coastal and deltaic regions create a narrow linear strip underlain by tertiary sediments and alluvium. Salinity is an inhibition for amelioration of groundwater despite highly potential aquifers present in these regions. Ahead of the coast, Rann of Kachchh and in parts of The Dangs, Surat and Bharuch districts, the shallow water levels of less than $5 \mathrm{mbgl}$ were identified $[95,96]$.
In Valsad and Kachchh, the average decadal rainfall ranges from $2338 \mathrm{~mm}$ to about $469 \mathrm{~mm}$ respectively. The average annual rainfall is 510 to $760 \mathrm{~mm}$ in Peninsular Gujarat though in the central parts around Junagarh it is higher up to $1100 \mathrm{~mm}$. In southern districts like Vadodara and Bharuch the difference of rainfall is from 760 to $1525 \mathrm{~mm}$, but in the neighborhood of Surat, Navsari and Valsad districts which are still more southern, it is higher ranging from $1525 \mathrm{~mm}$ to $2000 \mathrm{~mm}[95,96]$.

\subsection{Seawater intrusion in Gujarat}

Ingress of seawater by massive recession of groundwater and scanty rainfall, converts accessible resources of fresh groundwater to a saline belt among the coast of Gujarat. As a result, the cultivable lands turn barren, the water in the dug wells become saline which is unacceptable for agriculture and lose its portability. 779 villages with an extent of 1.65 million hectares and a population of 1.33 million are affected by salinity ingress as per the data of the year 1976 [97]. To recommend preventive measures for salinity ingress and establish remedial procedures to compensate the previous damages, High Level Committees (HLC) were appointed by Gujarat Government in the year 1976 and 1978. Accreditation of a yearly study to screen the areas exaggerated by the ingress of salinity was suggested by the HLCs. Similar yearly operation was latest done in year 2007-2008. An altogether augment of 15\% area in salinity ingress, involving a supplementary 88,947 hectares of exaggerated area was reported in comparison with the base data of the year 1977-1984.

During the time period from 1977 to 2008 , there were increase by $92 \%$ and $85 \%$ in the areas affected by SWI in Madhavpur-Malia and Lakhpat-Malia respectively. A loss of 1237 hectares was observed in Una-Madhavpur Reach due to inundation by seawater.

In the year 2007, Groundwater Resources Development Corporation (GWRDC) and Groundwater Division, Rajkot collected samples of groundwater from 88,626 observation wells of coastal zones and an analysis of groundwater quality was done [98]. The results reveal that the quality is unsafe and unacceptable in most of the areas as shown in Table 3. Presently, approximate $12 \%$ of the coastal terrestrial zone is saline, which is closed to a global average of $7 \%$. As the groundwater is declining by $3-5 \mathrm{~m} /$ year, causing the salinity ingress to $0.5-1.0 \mathrm{~km} /$ year.

The groundwater recourses of entire coastline had been affected by salinity ingress qualitatively. According to a baseline study, 540 villages out of total 1165 coastal villages were victims of drinking water knots like absence and lack of source and unacceptable quality of water [99].

Desai et al. [100] investigated hydrochemical characterization of SWI in the stretch of Mangrol-Chorwad 


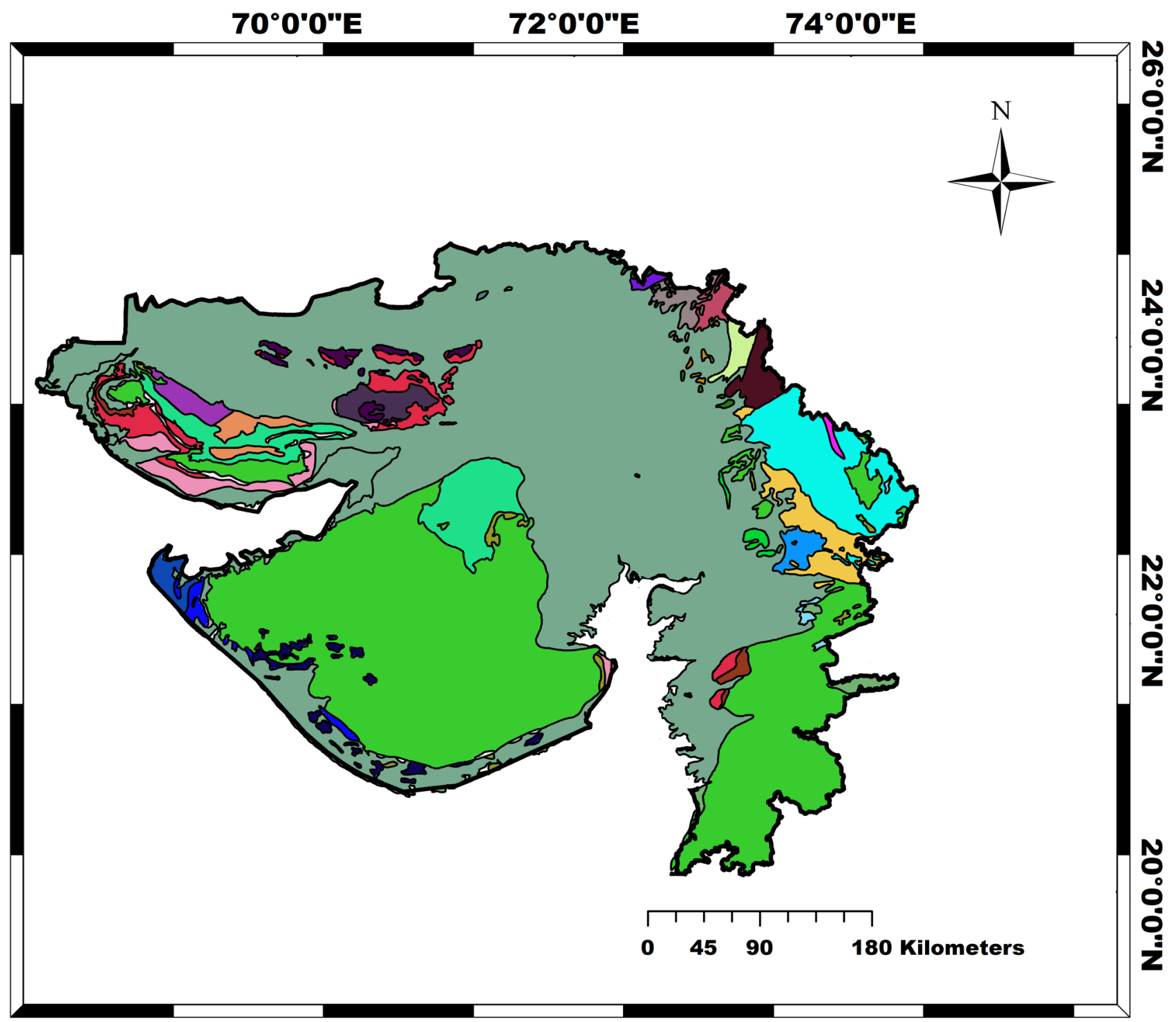

\section{EXPLANATION}

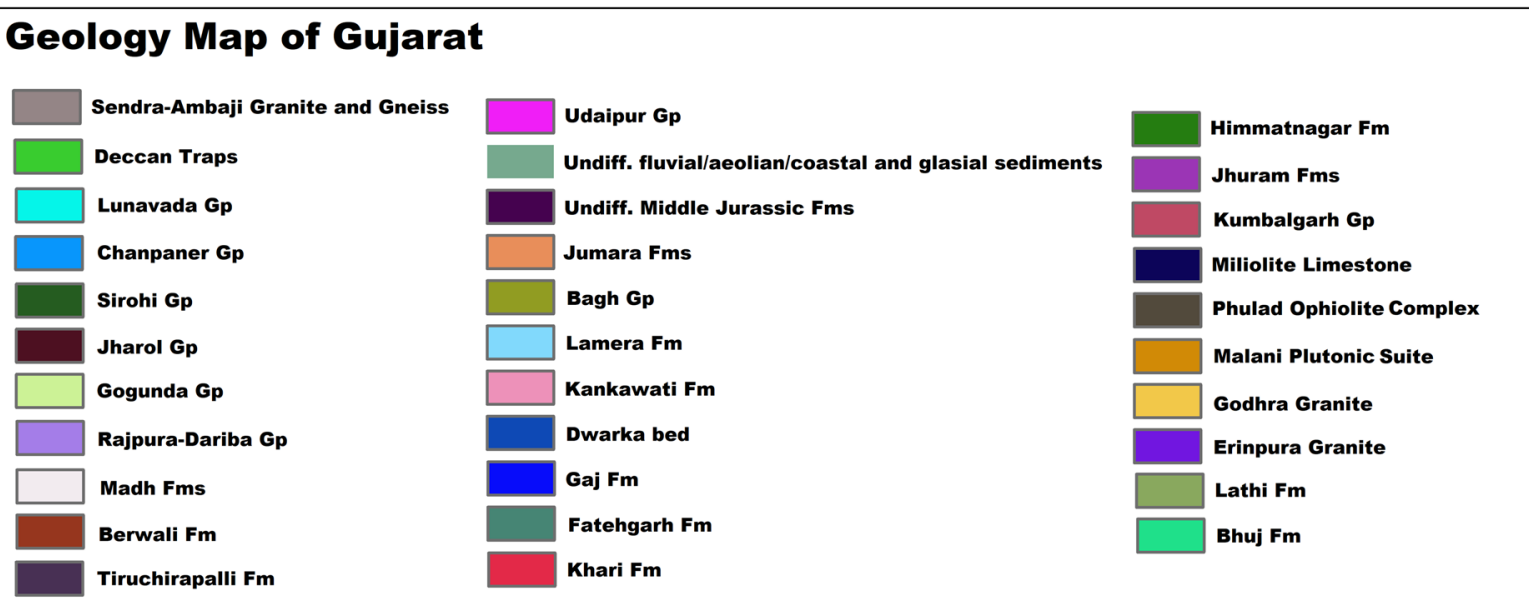

Fig. 3 Geological map of Gujarat (adopted from Bhukosh, Geological Survey of India) 
Table 3 Results of water samples collected from coastal areas. Source: Data provided by GWRDC and Groundwater Division, Rajkot, 2007 [98]

\begin{tabular}{|c|c|c|c|c|}
\hline \multirow[t]{2}{*}{ Parameters } & \multicolumn{4}{|c|}{ Water quality zones } \\
\hline & Freshwater zone & Low salinity zone & Medium salinity zone & High salinity zone \\
\hline Total dissolved solids (ppm) & $<2000$ & $2000-4000$ & $4000-6000$ & $>6000$ \\
\hline Number of Samples & 359 & 270 & 118 & 139 \\
\hline Percentage & 41 & 30 & 13 & 16 \\
\hline
\end{tabular}

coast, Saurashtra, Gujarat. To find out the reason of escalating salinity in the groundwater, the geohydrological and geochemical data of key aquifers in this province was analyzed. Three distinguishable categories of water, such as I, II and III based on the total ion chemistry and the $\mathrm{Cl}^{-} /\left(\mathrm{HCO}_{3}{ }^{-}+\mathrm{CO}_{3}{ }^{2-}\right)$ ratio was found. The representation of hydrochemical zonation followed the order from northeast to southwest with progressively greater salinity towards the coast.

The groundwater hazards evaluation was carried out in a coastal district Jamnagar of Gujarat [101]. From this study, it was revealed that, about 181 villages of this district were devastated by excess total dissolved solids, 39 villages with excess fluoride and 2 villages by means of both excess total dissolved solids (TDS) and fluoride. In this area, groundwater contamination was principally due to the natural salinity of rocks or sediments, seawater ingress. Toxic elements like lead $(\mathrm{Pb})$, nickel $(\mathrm{Ni})$ and radicals $\left(\mathrm{SO}_{4}{ }^{2-}, \mathrm{NO}_{3}{ }^{-}, \mathrm{Cl}^{-}\right.$and Fluoride) zones had been recognized and delineated in brackish groundwater. Analysis of the groundwater as well as SWI for the section of limestone zone of coastal Gujarat, India had been carried out [102]. Three different sites of limestone mines in proximity were distinguished covering a zone along the Gujarat coast, India with excess values of TDS (>4000 mg/L), $\mathrm{Cl}(>2000 \mathrm{mg} / \mathrm{L})$ and also the ratio of $\mathrm{Cl}^{-} / \mathrm{HCO}_{3}{ }^{-}>1$, were shown by the hydrochemical statistics of different groundwater samples. The presence of SWI into the coastal aquifer was assumed from these data. Measurement of WQI for groundwater in respect of SWI was studied at coastal area of Surat City [103]. APHA standard procedures were followed for hydrogeological and geochemical analysis of 25 collected samples of groundwater. In winter season, the WQI of the samples was ranged from 418.65-2281.15 and in summer season, it was 936.89-2411.65. Approximately, $99 \%$ of the samples surpassed the maximum of WQI for drinking water i.e. 100. The higher value of chloride, chemical oxygen demand (COD), fluoride, hardness, iron, salinity, and total dissolved solids in the groundwater caused higher values of WQI of these sampling sites. The permanent nature of hardness of water is indicated by the significant interrelation of magnesium and chloride. Identification of salinization in coastal aquifers of Sabarmati River
Basin was investigated by isotopes as well as ion chemistry. A study shows the electrical conductivity of shallow groundwater in the coastal borders generally varies from 1500 to $4500 \mu \mathrm{S} / \mathrm{cm}$ excluding in the region between Sikka and Hadiyana of Jamnagar coast [96]. Nevertheless, strips of Kachchh and Saurashtra coasts and parts of Gulfs of Kachchh and Khambat are also there with electrical conductivity values above $4500 \mu \mathrm{S} / \mathrm{cm}$. As the coastal tracts are influenced by SWI the quality of groundwater in the Miliolite limestone mostly in areas of 2-4 km inland from the coast is good. The quality of groundwater is generally just slightly fresh in owing to intrinsic salinity of groundwater formation and intercalation of clays. The shallow groundwater is mainly brackish to saline in the mainland coastal belts of southern Gujarat excluding more south in Valsad district where electrical conductivity is less than $1500 \mu \mathrm{S} / \mathrm{cm}$. In deeper aquifer the quality of groundwater is saline in large parts.

In Porbandar coast, $\mathrm{D}_{2}$ and ${ }^{18} \mathrm{O}$ isotopes on salinization of groundwater into adjacent saltpans were analyzed [104]. Water samples from different sources such as saltpans, dug wells, seawater and bore wells were collected and analyzed for various anions and cations. This study indicates that the deviation of ionic ratios $\left(\mathrm{Na}^{+} /\right.$ $\mathrm{Cl}^{-}, \mathrm{Ca}^{2+} / \mathrm{Mg}^{2+}$ and $\left.\mathrm{SO}_{4}{ }^{2-} / \mathrm{Cl}^{-}\right)$with $\delta^{2} \mathrm{H}$ and $\delta^{18} \mathrm{O}$ signifies that the saltpans are not responsible for the worsening in the quality of groundwater [105]. In this study, $\delta^{18} \mathrm{O}$ and $\delta^{2} \mathrm{H}$ isotopes were incorporated with ionic ratios to delineate SWI. The Hydrogeochemical evaluation of groundwater in Narmada-Mahi Inter-Stream region was studied to mark out suitability for irrigation and domestic purposes [106]. $\delta^{18} \mathrm{O}$ isotopic dissimilarity and allocation in groundwater samples of this area signifies that the quality of groundwater within this region is highly diverse as well as intricate due to influence of SWI, inherent sediment salinity, over-exploitation, and pollution. Stable isotopic study was conducted to assess SWI in coastal aquifers of Kachchh district [107]. According to the hydrochemical study, majority of the samples indicated $\mathrm{NaCl}$ type of facies. Various ionic ratios and stable isotopic study suggested that, the coastal regions are prone to SWI. Different cationic and anionic ratios like $\mathrm{SO}_{2}^{4}{ }^{-} / \mathrm{Cl}^{-}, \mathrm{Mg}^{2+} / \mathrm{Ca}^{2+}, \mathrm{K}^{+} / \mathrm{Cl}^{-}$and $\mathrm{Na}^{+} / \mathrm{Cl}^{-}$were analyzed. 
The salinity in groundwater in inland areas was persuaded due to variety of anthropogenic activities, overexploitation, and over-pumping.

In the year 2009, near Kovaya limestone mine, Saurashtra coast, SWI was studied [108]. In this study, total 27 dug wells were selected. Sampling had been done in April and September 2006. Excessive concentration of total dissolve solid (>1000 mg/L) and chloride (103-3899 mg/L) contents were revealed by the analysis of the groundwater samples. On selected profiles of study spot 'Resistivity Imaging Survey' had correspondingly been implemented. The lowest zones of resistivity $(0-3 \mathrm{~m})$ were diagnosed within the underneath part of the resistivity depth through the electrical resistivity tomography images. SWI might be interpreted by these low resistivity zones. In close boundaries of seashore, anticipation of SWI for mining activity was studied by Singh et al. (2013) [109]. The study area is located $30 \mathrm{~km}$ towards the southern part of Bhavnagar district and belongs to Gujarat Mineral Development Corporation (GMDC). By means of Ghyben-Herzberg principle regarding freshwater-salinewater interface, remote sensing and ground authentication were used to study the SWI into the lease area of entire mining portion. Monitoring of groundwater table and electrical resistivity survey were performed in the year 2004. The result of study manifests the absence of SWI here. In Surka Mining Lease Area, Gujarat, the geophysical classification of salinity ingress was studied by Singh et al. (2015) [110]. The high salinity ingress along the entire stretch of Rampar River had been observed. Instability between tidal water cycle and oceanic deposition owing to involvement among mature strand lines might be the probable reasons. The conspicuous factors such as inherent salinity, tidal reversal and marshy land along shore zone are responsible for the foremost causes of salinity ingress observed in this region.

Impact of seawater intrusion on coastal aquifer of Bhavnagar was studied by Pateliya et al. (2016) using GALDIT method [111]. Following parameters such as groundwater incidence like aquifer category (confined, leaky confined and unconfined), hydraulic conductivity of aquifer, groundwater level with respect to mean sealevel, the distance of inland with perpendicular to shoreline, effect of accessible condition of SWI in the region and depth of aquifer are the basic of GALDIT index. Each of the GALDIT factor has been assessed through the variant by conveying a relative weight to establish the relative importance of each factor. Every six parameters have encoded with a preset weight, which indicates its relative importance to SWI. GALDIT map of Bhavnagar coastal area indicated that maximum part of this coastal zone is not vulnerable to salinity ingress. Around $85 \%$ area have low vulnerability, $10 \%$ area have medium vulnerability and $5 \%$ area is highly vulnerable.

\subsubsection{Modeling of seawater intrusion in Gujarat}

Numerous studies related to SWI and the modeling of solute transport is executed to manage the vast coastal zones of India [62]. In India, numerous models for SWI are bestowed by various research groups using various numerical modeling software like MODFLOW, SEAWAT, FEFLOW, GALDIT, NEWSAM etc. which provide more convenient and esteemed techniques to assess, understand and forecast SWI $[112,113]$.

Groundwater modeling was also applied in coastal aquifer of Veraval area of Gujarat [114]. In this study, SUTRA (Saturated-Unsaturated TRAnsport) model, the latest version i.e. V09972D was employed to simulate the process of SWI. Extracting and influx of coastal region was predicted for three distinctive periods of time (May 1975, Nov 1976, and May 1995) using the model. Under steady state environments, the SWI was modeled in coastal region of Saurashtra, Gujarat. Hele-Shaw model of SWI was studied around Surat city, Gujarat [115]. The mode Hele-Shaw was used in this study to assess the progress and shifting of seawater interface both the condition (with and without) of recharge state for three different regions of Surat City. To analyze the magnitude of worsening in the quality of groundwater, the physico-chemical parameters were also determined. To quantify the parameters, it is much essential to formulate the model from the information of the observation well. Owing to the recharge rates of $2.175 \times 10^{-3} \mathrm{~m}^{3} / \mathrm{s} / \mathrm{m}$ and $10.73 \times 10^{-3}$ $\mathrm{m}^{3} / \mathrm{s} / \mathrm{m}$, the revulsion of intrusion in initial condition was estimated to be $90 \%(17.91 \mathrm{~km})$ and $50 \%(9.95 \mathrm{~km})$. Shah et al. (2015) assessed the temporal and spatial changes of salinity by Inverse Distance Weighted Modeling in ArcGIS [116]. Last 15 years data of well location and corresponding quality data of GWRDC were used to generate 2D maps of spatial distribution of Static Water Level (SWL), Chloride (Cl) and Electrical Conductivity (EC) to study the temporal and spatial distribution of the salinity for the periods of preand post-monsoon. These maps were used to detect the interchange of the seawater and freshwater interface and subsequent SWI over the last 15 years, if any. The study concluded that, the groundwater has become more saline over the years. As per the Ghyben-Herzberg principle, in some of the region, the seawater level has been increased over the years which are directly distressing the groundwater quality.

\section{Impact of salinity contamination in Gujarat}

\subsection{Health impact}

Kidney stones, fluorosis, intestinal ailments, and many other diseases due to intake of brackish water affected 
Coast dwellers. Coastal Salinity Prevention Cell (CSPC) accomplished a baseline study on 1165 villages in the year 2007-2008 (Table 4) [117].

\subsection{Ecological impact}

Impacts of SWI are principally coupled with deprivation of resources of freshwater and contamination of the wells meant for supply. The degradation of environment due to $\mathrm{SWI}$ is universally connected with the agrarian use of the groundwater of high salinity. Consequently, it altered the chemistry of soil and reduced its fertility $[118,119]$. Salinity of the soil adversely affects crop productivity. Salt sensitive crops like pulses and oil seeds suffer a lot because of excess soil and groundwater salinity [119].

\subsection{Socioeconomic impact}

In the coastal areas of Saurastra, salinity has been observed to victimize 0.7120 million hector areas, 534 villages, 1.88 million people and 32,750 wells. Because of deterioration in quality of groundwater due to salinity, undesirable consequence on farming products and agriculture-based industries due to over-pumping by farmers, the economic condition of this area was highly affected. For these reasons, also migration of community is increasing toward the nearby urban areas.

\section{Management plans for coastal aquifers in Gujarat}

The management of coastal aquifers includes socioeconomic and environmental well-being obtained from coastal groundwater assets. Today's challenge for environmental managers is to install efficient techniques to regulate SWI and facilitate a flawless exploitation of groundwater resource.

In the literature, earlier research works have anticipated numerous counter tools and techniques to restrain or mitigate SWI. These control and management approaches may be concise into two core methods: (1) utilization of hydraulic barriers (artificial recharge techniques) to balance the freshwater head loss; and (2) construction of the subsurface physical barriers to decrease the intrusion or to prevent it [120]. The other type is the sub-water-storage blocks with an infrastructure tie upon bedrock of the aquifer and an unwrap crest next to the higher division of the aquifer [121, 122]. The sub-water dams are most practicably used in areas with $1^{\circ}-5^{\circ}$ slope [123]. According to their study, the subsurface barriers are favorably built in the sites with greater hydraulic conductivity like deep alluvial layers, riverbeds with sand and gravel and weathered zones.

\section{Way forward}

The most important scientific challenge meant for SWI management in coastal aquifer of Gujarat is the execution of SWI awareness, pertaining to hydrogeochemical processes, investigative mechanisms, and management approaches. The detailed geometrical studies of aquifer, circulation of the freshwater and brackish water within the system, regular monitoring of the withdrawal and interchange of freshwater and salinewater interface are most important to manage the groundwater system. Engineering and pumping control techniques require being integrated into decision support systems, connecting between biophysical models with societal constraints, as efficient in advance fields of management of water resources. An innovative barrier system, the mixed physical barrier system (MPB) integrated with an impervious cut off barrier and semi-permeable subsurface can also be constructed to control the SWI. This technique is more applicable in aquifers with high hydraulic conductivity (e.g. gravel, sand, silt) in which the velocity of groundwater flow is high. The artificial recharge by surface water infiltration is another engineering technique, which universally applicable to resolve this dilemma. This technique is applied to boost the piezometric levels and to upgrade the quality of the groundwater. Diminution of abstraction from wells through pumping is the easiest, shortest, and lucrative measure to sustain the groundwater balance within the aquifer system and manage the dilemmas of SWI. Nevertheless, this prospect of decreasing the abstraction can be
Table 4 Villages affected by various diseases at various distances from sea coast. Source: Compiled from data provided by CSPC, Ahmedabad, 2007-2008 [117]

\begin{tabular}{lllrl}
\hline Total no. of villages facing health problems & \multicolumn{3}{l}{ Diseases type } \\
\cline { 3 - 5 } & & Kidney stones & Fluorosis & $\begin{array}{c}\text { Intestinal } \\
\text { Problems }\end{array}$ \\
& & & 337 & 753 \\
\hline Distance of affected villages from sea coast & $<5 \mathrm{~km}$ & 347 & 151 & 307 \\
& $5-10 \mathrm{~km}$ & 236 & 87 & 99 \\
& $>10 \mathrm{~km}$ & 307 & 207 & 277 \\
\hline
\end{tabular}


restrained within certain areas with respect to the requirement of groundwater needs [124]. Apparently, an ancillary supply of water must be premediated to replace the groundwater abstraction/pumping.

Artificial recharge via injection well and/or pond infiltration is implemented utmost largely to reduce salinity in unconfined coastal aquifers [125]. From diverted surface water, both the injectant and infiltrant are obtained. This surface water could be an amalgamation of runoff from natural sources, synchronized flows from reservoirs, and freshwater imported by other natural sources [126].

GIS integrated with geophysical methods like vertical electrical sounding (VES), electrical resistivity tomography (ERT) and ground penetrating radar (GPR) are eminent technique to identify salinewater intrusion [127]. These geophysical techniques should be applied to identify and forecast SWI in the coastal region of Gujarat.

\section{Conclusion}

In this study, we have undertaken an evaluation of the vulnerability of Gujarat's coastal aquifers to SWI. We also focus on the various scientific studies and management options which can be adopted here to combat with the menace of SWI. Therefore, it can be concluded from the present study that for impact assessment of SWI on surrounding environment, the capability of engineering techniques should be enhanced by involving additional widespread investigation tools such as hydro-ecological study of the coastal regions. There is a need for more expertise and experience of the local researcher within the region to develop a larger dimension to invent and apply additional innovative techniques to investigate the SWI with collaborating and facilitating the accessibility of previous data of groundwater. This will create much potential to perceive trends in the seawater ingress into the aquifer system of the coast and build forthcoming predictions of probable circumstances under diverse climatic and anthropogenic environments.

Furthermore, due to the extensive differences in geological, geomorphological, and climatic structure along the Gujarat coast, it is desirable to implement the mitigation approaches based on local circumstances. Nevertheless, it is much desirable that involvement, association, and dynamic contribution of each individual at the local level are essential for effective management of SWI. The primary importance is the awareness among the communities reside in coastal regions for the sustainable development of coastal groundwater resources.

Acknowledgements The authors are very much thankful to Honorable Vice-Chancellor of the Central University of Gujarat, Prof. Rama Shanker Dubey and Dr. Bhawana Pathak, Associate professor and
Dean, School of Environment and Sustainable Development (SESD), Central University of Gujarat (CUG), Gandhinagar for providing the infrastructure to carry out the research. We acknowledge Central Groundwater Board, Ahmadabad, and Gujarat Water Resource Development Corporation, Gandhinagar, for their support. The first author is thankful to University Grant Commission for giving her Non-NET Fellowship to continue this research work.

\section{Compliance with ethical standards}

Conflicts of interest The authors declare that they have no known conflict of financial interests or personal relationships that could have appeared to influence the work reported in this paper.

\section{References}

1. Thomas M, Hafsath S, Mohamed ST (2017) Assessment of salt water intrusion into the coastal aquifers of Kerala. Int Res J Eng Technol 04(02):726-729

2. Kantamaneni K, Du X, Aher S, Singh RM (2017) Building blocks: a quantitative approach for evaluating coastal vulnerability. Water 9:905. https://doi.org/10.3390/w9120905

3. Neumann B, Vafeidis AT, Zimmermann J, Nicholls RJ (2015) Future coastal population growth and exposure to sea-level rise and coastal flooding - a global assessment. PLoS One 10:e0118571. https://doi.org/10.1371/journal.pone.0118571

4. Manivannan V, Elango L (2019) Seawater intrusion and submarine groundwater discharge along the Indian coast. Environ Sci Pollut Res 26:31592-31608. https://doi.org/10.1007/s1135 6-019-06103-z

5. Werner AD, Ward JD, Morgan LK, Simmons CT, Robinson NI, Teubner MD (2012) Vulnerability indicators of sea water intrusion. Ground Water 50:48-58. https://doi.org/10.111 1/j.1745-6584.2011.00817.x

6. Kumar P, Bansod B, Debnath S, Thukar P, Ghanshyam C (2015) Index-based groundwater vulnerability mapping models using hydrogeological settings: a critical evaluation. Environ Impact Assess Rev 51:38-49

7. Badaruddin S, Werner AD, Morgan LK (2017) Characteristics of active seawater intrusion. J Hydrol 551:632-647

8. Carr PA (1969) Salt-water intrusion in Prince Edward Island. Can J Earth Sci 6:63-74

9. Larsen F, Tran LV, Van H, Tran LT, Christiansen AV, Pham NQ (2017) Groundwater salinity influenced by Holocene seawater trapped in incised valleys in the Red River delta plain. Nat Geosci 10:376-381. https://doi.org/10.1038/ngeo2938

10. Vann S, Puttiwongrak A, Suteerasak T, Koedsin W (2020) Delineation of seawater intrusion using geo-electrical survey in a coastal aquifer of Kamala Beach, Phuket, Thailand. Water 12:506. https://doi.org/10.3390/w12020506

11. Van dam JC, Meulenkamp JJ (1967) Some results of the geoelectrical resistivity method in ground water investigations in the Netherlands. Geophys Prospect 15:92-115. https://doi. org/10.1111/j.1365-2478.1967.tb01775.x

12. Nowroozi AA, Stephen $B H$, Henderson $P$ (1999) Saltwater intrusion into the freshwater aquifer in the eastern shore of Virginia: a reconnaissance electrical resistivity survey. J Appl Geophys 42:1-22

13. Khan MYA, Gani KM, Chakrapani GJ (2017) Spatial and temporal variations of physicochemical and heavy metal pollution in Ramganga River: a tributary of River Ganges, India. Environ Earth Sci 76:231 
14. Ledesma-Ruiz R, Pastén-Zapata E, Parra R, Harter T, Mahlknecht $J(2015)$ Investigation of the geochemical evolution of groundwater under agricultural land: a case study in northeastern Mexico. J Hydrol 521:410-423

15. Sun Z, Song $X, B u H$, Yang L, Ma Y, Zhang $Y$, Han D (2016) Origin of groundwater salinity and hydrochemical processes in an unconfined aquifer: case of Yang-Dai River basin in Qinhuangdao (China). Environ Earth Sci 75:54

16. Behera AK, Chakrapani GJ, Kumar S, Rai N (2019) Identification of seawater intrusion signatures through geochemical evolution of groundwater: a case study based on coastal region of the Mahanadi delta, Bay of Bengal, India. Nat Hazards 97:12091230. https://doi.org/10.1007/s11069-019-03700-6

17. Qi SZ, Qiu QL (2011) Environmental hazard from saltwater intrusion in the Laizhou Gulf. Shandong Province of China. Nat Hazards 56:563-566

18. Werner A, Bakker M, Post V, Vandenbohede A, Lu C, AtaieAshtiani B, Simmons C, Barry D (2013) Seawater intrusion processes, investigation and management: recent advances. Adv Water Resour 51:3-26

19. Baskaran V, Mangalam M, Murugaiyan V (2016) Study of seawater intrusion in a coastal aquifer by hydrochemical method-a review. Int J Adv Res 4(2):120-126

20. CGWB (2014) Report on status of groundwater quality in coastal aquifers of India. Bhujal Bhawan, Faridabad

21. World Bank (2010) Deep wells and prudence: towards pragmatic action for addressing groundwater overexploitation in India. Report, World Bank, Washington, DC

22. Rodell M, Famiglietti JS, Wiese DN, Reager JT, Beaudoing HK, Landerer FW, Lo MH (2018) Emerging trends in global freshwater availability. Nature 557:651-659

23. Panda DK, Wahr J (2016) Spatiotemporal evolution of water storage changes in India from the updated GRACE-derived gravity records. Water Resour Res 52:135-149

24. Keesari T, Sinha UK (2019) Palaeo-seawater of Kutch region, Gujarat, India. Curr Sci 116(8):1407-1410

25. Gururaja Rao G, Kanani AD, Purohit D, Waghela D (2019) Coastal saline soils of Gujarat (India): problems, reclamation measures and management strategies. In: Dagar J, Yadav R, Sharma P (eds) Research developments in saline agriculture. Springer, Singapore. https://doi.org/10.1007/978-981-13-5832-6_21

26. Ahmed AT, Askri B (2016) Seawater intrusion impacts on the water quality of the groundwater on the northwest coast of Oman. Water Environ Res 88(8):732-740

27. D\&MI (1992) Water and wastewater masterplan for Salalah; Office of The Minister of State and Governor of Dhofar. Sultanate of Oman, Salalah

28. Badon-Ghyben W (1889) Nota in verband met de voorgenomen put boring nabij Amsterdam: Koninkl Inst. Ing. Tijdschr. 1889 (The Hague), pp 21

29. Herzberg A (1901) Die Wasserversorgung einiger Nordseebader: Gasbeleucht. u. Wasserversorg. Jahrb. Jahrg, pp 44, Munich

30. Healy RW, Winter TC, LaBaugh JW, Franke OL (2007) Water budgets: Foundations for effective water-resources and environmental management: U.S. Geological Survey Circular, 1308, p 90

31. Tarul S, Praveen T, Bhaskar N, Garg V (2013) Water budget components estimation using satellite data and a hydrological model. In: Proceedings of hydro international, 4-6 December, IIT Madras, India

32. Roo AD, Peter $B$, Alessandro $G$, Angel U, Faycal B, Alberto A, Alessandra B, Alessandra LN, Onno K et al. (2012) A multi-criteria optimisation of scenarios for the protection of water resources in Europe: Support to the EU blueprint to safeguard Europe's waters. European Commission Joint
Research Centre, Institute for Environment and Sustainability. JRC75919, ISBN 978-92-79-27025-3

33. Kossida M, Lourmas G, Avramidi E, Bouziotas D et al. (2012) Report on the water balances, following the standard SEEAW format. ABOT project Deliverable D.C2. ABOT "Assessment of water Balances and Optimisation based Target setting across EU River Basins", Preparatory Action on development of prevention activities to halt desertification in Europe Halting desertification in Europe-2011, DG ENV

34. European Commission (2015) Guidance document on the application of water balances for supporting the implementation of the WFD. Technical Report, p 126

35. Yihdego Y, Khalil A (2017) Groundwater resources assessment and impact analysis using a conceptual water balance model and time series data analysis: case of decision making tool. Hydrology 4:25. https://doi.org/10.3390/hydrology4020025

36. Alley WM, Reilly TE, Franke OL (1999) Sustainability of ground-water resources. U.S. Geological Survey Circular, Denver

37. California Department of Water Resources, CDWR (2006) Progress on incorporating climate change into management of California's water resources. Sacramento, California

38. Nicholls RJ, Cazenave A (2010) Sea-level rise and its impacts on coastal zones. Science 328:1517-1520

39. Anderson J, Miliken K, Wallace D (2010) Coastal impact underestimated from rapid sea level rise. EOS Trans Am Geophys Union 91(23):205-206

40. Delsman JR, Hu-a-ng KRM, Vos PC, de Louw PGB, Oude Essink GHP, Stuyfzand PJ, Bierkens MFP (2014) Paleo-modeling of coastal saltwater intrusion during the Holocene: an application to the Netherlands. Hydrol Earth Syst Sci 18:3891-3905. https://doi.org/10.5194/hess-18-3891-2014

41. Han DM, Song XF, Currell MJ, Yang JL, Xiao GQ (2014) Chemical and isotopic constraints on evolution of groundwater salinization in the coastal plain aquifer of Laizhou Bay, China. J Hydrol 508:12-27

42. Saltwater intrusion and climate change Report (2011) Prince Edward Island Department of Environment, Labour and Justice. 11 Kent Street, Charlottetown, PE, C1A 7N8

43. Cruickshanks FB, Gibb JE, Hennigar TW (1987) Groundwater management issues in the Atlantic Provinces. Inland Waters and Lands. Conservation and Protection, Environment Canada, Dartmouth

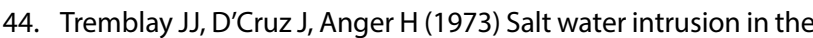
Summerside area, P.E.I. Groundwater 11(2):21-27

45. Cross HJ (1980) Report on test drilling program, Upper Lawrencetown, Halifax County. Nova Scotia Department of the Environment, Water Planning and Management Division, Halifax

46. Rivard C, Michaud Y, Lefebvre R, Deblonde C, Rivera A (2008) Characterization of a regional aquifer system in the Maritimes Basin, Eastern Canada. Water Resour Manag 22(11):1649-1675

47. Somers GH, Nishimura PH (2012) Managing groundwater resources-assessing the impact of climate change on saltwater intrusion of coastal aquifers in Atlantic Canada. Prince Edward Island Department Environment, Labour and Justice, Greewich. https://doi.org/10.13140/rg.2.1.2757.6802

48. Bolster DT, Tartakovsky DM, Dentz M (2007) Analytical models of contaminant transport in coastal aquifers. Adv Water Resour 30:1962-1972

49. Edwards BD, Evans KR (2013) Saltwater intrusion in Los Angeles area coastal aquifers-The marine connection; USGS Fact Sheet 030-02. http://pubs.usgs.gov/fs/2002/fs03

50. Meyer R, Engesgaard P, Sonnenborg TO (2019) Origin and dynamics of saltwater intrusion in a regional aquifer: combining 3-D saltwater modeling with geophysical and 
geochemical data. Water Resour Res 55:1792-1813. https:// doi.org/10.1029/2018WR023624

51. Idowu TE, Lasisi KH (2020) Seawater intrusion in the coastal aquifers of East and Horn of Africa: a review from a regional perspective. Scientific African 8:1-15. https://doi.org/10.1016/j. sciaf.2020.e00402

52. Steyl G, Dennis I (2010) Review of coastal-area aquifers in Africa. Hydrogeol J 18:217-225. https://doi.org/10.1007/s1004 0-009-0545-9

53. Tole MP (1997) Pollution of groundwater in the coastal Kwale District, Kenya, sustainability of water resources under increasing uncertainty (Proceedings of the Rabat Symposium S1, April 1997). IAHS Publ. no. 240

54. Samson O, Jean-Christophe C (2019) Drivers, patterns and velocity of saltwater intrusion in a stressed aquifer of the East African coast: joint analysis of groundwater and geophysical data in Southern Kenya. J Afr Earth Sci 149(1):334-347. https ://doi.org/10.1016/j.jafrearsci.2018.08.016

55. Elsheikh A, Zeinelabdein KAE (2015) Sea water/fresh water interaction in the Red Sea coast around Port-Sudan town-Red Sea State, Nile. Water Sci Eng J 8:67-73

56. Werner AD (2010) A review of seawater intrusion and its management in Australia. Hydrogeol J 18(1):281-285

57. Morgan LK, Werner AD (2015) A national inventory of seawater intrusion vulnerability for Australia. J Hydrol Region Stud 4:686-698. https://doi.org/10.1016/j.ejrh.2015.10.005

58. Werner AD, Ward JD, Morgan LK, Simmons CT, Robinson NI, Teubner MD (2012) Vulnerability indicators of seawater intrusion. Ground Water 50(1):48-58

59. Morgan LK, Werner AD (2014) Seawater intrusion vulnerability indicators for freshwater lenses in strip islands. J Hydrol 508:322-327. https://doi.org/10.1016/j.jhydrol.2013.11.002

60. Zhou Y, Li W (2011) A review of regional groundwater flow modeling. Geosci Front 2(2):205-214

61. Ding F, Yamashita T, Soo LH, Jun P (2014) A modelling study of seawater intrusion in the liao dong bay coastal plain, China. J Mar Sci Technol 22(2):103-115

62. Magesh NS, Chandrasekar N, Elango L (2017) Trace element concentrations in the groundwater of the Tamiraparani river basin, South India: insights from human health risk and multivariate statistical techniques. Chemosphere 1:1. https://doi. org/10.1016/j.chemosphere.2017.07.044

63. Wang J, Li L, He Z, Kalhoro NA, Xu D (2019) Numerical modelling study of seawater intrusion in Indus River Estuary, Pakistan. Ocean Eng 184:74-84. https://doi.org/10.1016/j.ocean eng.2019.05.029

64. Mahdieh D, Akbar AJ, Mohammad A, Kai-Yuan K, Raziyeh F, Yih-Chi T, Albert SC (2020) Modelling seawater intrusion in the Pingtung coastal aquifer in Taiwan, under the influence of sealevel rise and changing abstraction regime. Hydrogeol J. https ://doi.org/10.1007/s10040-020-02172-4

65. Post VEA, Essink GO, Szymkiewicz A, Bakker M, Houben G, Custodio E, Voss C (2018) Celebrating 50 years of SWIMs (Salt Water Intrusion Meetings). Hydrogeol J. https://doi.org/10.1007/ s10040-018-1800-8

66. Verruijt A (1972) Analysis of interface problems by the finite element method. SWIM 3:53-59

67. Zechner E, Zidane A, Younes A, Huggenberger P (2014) Simulation of high-contrast density driven transport. SWIM 22:247-250

68. Bauer P, Zimmermann S, Held R, Gumbricht T, Kinzelbach W (2002) Is density flow balancing the salt budget of the Okavango delta? Evidence from field and modelling studies. SWIM 17:309-321

69. Kathrani N, Kandya A, Koekkoek I, Kelder TOD, Rajpurohit P (2017) From the problem of ground water salinity towards sustainable prosperity in agricultural sector in Coastal Region of Gujarat, India. In: Proceedings of the 2 nd World Congress on Civil, Structural, and Environmental Engineering (CSEE'17), Barcelona, Spain-April 2-4, Paper No. AWSPT 156, ISSN: 23715294, https://doi.org/10.11159/awspt17.156

70. ICZMP (2010) Document of world bank-project appraisal document for an integrated coastal zone management project. Report no: 54612-IN. http://www.sicommoef.in/Data/Sites/1/ skins/gec-sicom/images/docs/pad.pdf

71. Kumar VS, Pathak KC, Pednekar P, Raju NSN, Gowthaman R (2006) Coastal processes along the Indian coastline. Curr Sci 91(4):530-536

72. Thilagavathi R, Chidambaram S, Prasanna MV, Thivya C, Singaraja C, Jainab I (2012) A study on groundwater geochemistry and water quality in layered aquifers system of Pondicherry region, southeast India. Appl Water Sci 2:253-269. https://doi. org/10.1007/s13201-012-0045-2

73. Singaraja C, Chidambaram S, Anandhan P, Prasanna MV, Thivya C, Thilagavathi R (2015) A study on the status of saltwater intrusion in the coastal hard rock aquifer of South India. Environ Dev Sustain 17:443-475. https://doi.org/10.1007/s1066 8-014-9554-5

74. Kumar KSA, Priju CP, Prasad NBN (2015) Study on Saline Water intrusion into the Shallow Coastal Aquifers of Periyar River Basin, Kerala using Hydrochemical and Electrical Resistivity Methods. International conference on water resources, coastal and ocean engineering (ICWRCOE 2015). Aquatic Procedia 4:32-40

75. Satheeskumar V, Subramani T, Lakshumanan C, Roy PD, Karunanidhi D (2020) Groundwater chemistry and demarcation of seawater intrusion zones in the Thamirabarani delta of south India based on geochemical signatures. Environ Geochem Health. https://doi.org/10.1007/s10653-020-00536-z

76. Sivaranjani S, Ellappan V, Karthick LA (2019) Appraisal of seawater mixing index in coastal aquifer of Karaikal, Southern India using geospatial technology. J Geol Soc India 94:641-644. https://doi.org/10.1007/s12594-019-1371-x

77. Nair IS, Rajaveni SP, Schneider M, Elango L (2015) Geochemical and isotopic signatures for the identification of seawater intrusion in an alluvial aquifer. J Earth Syst Sci 124:1281-1291

78. Mohanty AK, Rao VSSG (2019) Hydrogeochemical, seawater intrusion and oxygen isotope studies on a coastal region in the Puri District of Odisha, India. Catena 172:558-571. https:// doi.org/10.1016/j.catena.2018.09.010

79. Das S, Maity PK, Das R (2018) Remedial measures for saline water ingression in coastal aquifers of South West Bengal in India. MOJ Ecol Environ Sci 3:1. https://doi.org/10.15406/mojes .2018.03.00061

80. Maity PK, Das S, Das R (2017) Methodology for groundwater extraction in the coastal aquifers of Purba Midnapur District of West Bengal in India under the constraint of saline water intrusion. Asian J Water Environ Pollut 14:1-12. https://doi. org/10.3233/AJW-170011

81. Majumdar RK, Kar S, Panda A, Samanta SK (2016) Hydrological characterization of Budge Budge and Dum Dum areas of south and north 24 Parganas districts. West Bengal using geoelectric and geochemical methods. J Geol Soc India 88:330-338. https ://doi.org/10.1007/s12594-016-0495-5

82. Majumdar RK, Kar S, Talukdar D, Duttagupta T (2014) Geoelectric and geochemical studies for hydrological characterization of canning and adjoining areas of South 24 Parganas district, West Bengal. J Geol Soc India 83:21-30. https://doi. org/10.1007/s12594-014-0003-8

83. Kantamaneni K, Rani NNVS, Rice L, Sur K, Thayaparan M, Kulatunga U, Rege R, Yenneti K, Campos L (2019) A systematic review of coastal vulnerability assessment studies along 
Andhra Pradesh, India: a critical evaluation of data gathering, risk levels and mitigation strategies. Water 11(393):1-22. https ://doi.org/10.3390/w11020393

84. Surinaidu L, Rao VVSG, Mahesh J, Prasad PR, Rao GT, Sarma VS (2015) Assessment of possibility of saltwater intrusion in the central Godavari delta region, Southern India. Reg Environ Chang 15:907-918. https://doi.org/10.1007/s10113-014-0678-9

85. Omprakash MD, Gadikar N (2018) Salt Water Intrusion and Water Security Issues of Coastal Community: Case of Thane District (Maharashtra). In: Water resources management. Springer, Singapore, pp 167-177. https://doi. org/10.1007/978-981-10-5711-3_12

86. Keesari T, Kulkarni UP, Jaryal A, Mendhekar GN, Deshmukh KN, Hegde AG, Kamble SN (2014) Groundwater dynamics of a saline impacted coastal aquifer of western Maharashtra, India: insights from a radiotracer study. J Radioanal Nucl Chem 300:16. https://doi.org/10.1007/s10967-014-2940-5

87. Vyshali PM, Mahesha A (2008) Simulation of saltwater intrusion in the Pavanje-Gurpur basins of Karnataka. ISH J Hydraul Eng 14:49-60. https://doi.org/10.1080/09715010.2008.10514904

88. Ravikumar P, Somashekar RK (2017) Principal component analysis and hydrochemical facies characterization to evaluate groundwater quality in Varahi river basin, Karnataka State. India. Appl. Water Sci. 7:745-755. https://doi.org/10.1007/ s13201-015-0287-x

89. Prusty P, Farooq SH (2020) Seawater intrusion in the coastal aquifers of India - A review. HydroResearch 3:61-74. https:// doi.org/10.1016/j.hydres.2020.06.001

90. Gopinath S, Srinivasamoorthy K, Saravanan K, Suma CS, Prakash R, Senthilnathan D, Chandrasekaran N, Srinivas Y, Sarma VS (2016) Modeling saline water intrusion in Nagapattinam coastal aquifers, Tamilnadu, India. Model Earth Syst Environ 2(2):1-10. https://doi.org/10.1007/s40808-015-0058-6

91. Kanagaraj G, Elango L, Sridhar SGD, Gowrisankar G (2018) Hydrogeochemical processes and influence of seawater intrusion in coastal aquifers south of Chennai, Tamil Nadu, India. Environ Sci Pollut Res 25:8989-9011. https://doi.org/10.1007/ s11356-017-0910-5

92. Sathish S, Elango L (2016) An integrated study on the characterization of freshwater lens in a coastal aquifer of Southern India. Arab J Geosci 9(643):1-17. https://doi.org/10.1007/s1251 7-016-2656-7

93. Senthilkumar S, Vinodh K, Babu GJ, Gowtham B, Arulprakasam $V$ (2019) Integrated seawater intrusion study of coastal region of Thiruvallur district, Tamil Nadu, South India. Appl Water Sci 9:124. https://doi.org/10.1007/s13201-019-1005-x

94. Seenipandi K, Nainarpandian C, Kandathil RK, Sellamuthu S (2019) Seawater intrusion vulnerability in the coastal aquifers of southern India - an appraisal of the GALDIT model, parameters' sensitivity, and hydrochemical indicators. Environ Sci Pollut Res 26:9755-9784. https://doi.org/10.1007/s11356-01904401-0

95. CGWB (2016) Regional Office Data Centre Central Ground Water Board West Central Region, Ahmedabad, p 185

96. Central Water Commission (2017) A report on Problems of Salination of Land in Coastal Areas of India and Suitable Protection Measures. Hydrological Studies Organization, New Delhi

97. Salinity Ingress Prevention Programme (2010) Narmada, water resources. Water supply and Kalpsar Department, Audit Report No, $p 2$

98. GWRDC (Gujarat Water Resource Development Corporation) (2007) Groundwater Division, Rajkot

99. Kathrani N, Kandya A, Koekkoek I, Kelder TOD, Rajpurohit P (2017) From the Problem of Ground Water Salinity towards Sustainable Prosperity in Agricultural Sector in Coastal Region of Gujarat, India. In: Proceedings of the 2 nd world congress on civil, structural, and environmental engineering (CSEE'17), Barcelona, Spain-April 2 - 4, Paper No. AWSPT 156, ISSN: 23715294, https://doi.org/10.11159/awspt17.156

100. Desai BI, Gupta SK, Shah MV (1979) Hydrochemical evidence of sea water intrusion along the Mangrol-Chorwad coast of Saurashtra, Gujarat. Hydrol Sci-Bulletin-des Sciences Hydrologiques 24(1):71-82

101. Das S, Prakash I (2008) Assessment of groundwater hazards in a coastal district of Gujarat, India. In: 6th International Conference on Case Histories in Geotechnical Engineering, Arlington, VA

102. Soni AK, Pujari PR (2010) Ground water vis-a-vis sea water intrusion analysis for a part of limestone tract of Gujarat Coast, India. J Water Resource Prot 2:462-468. https://doi.org/10.4236/jwarp .2010 .25053

103. Desai B, Desai $H$ (2012) Assessment of water quality index for the Ground water with respect to salt water Intrusion at coastal region of Surat City, Gujarat, India. J Environ Res Dev 7(2):607-621

104. Chandrasekharan H, Gupta N, Navada SV (1997) Deuterium and oxygen-18 isotopes on groundwater salinization of adjoining salt pans in Porbandar coast, Gujarat, India. Hydrochemistry (Proceedings of the Rabat Symposium). IAHS Publ 244:207-215

105. Kumari R, Datta PS, Singh CK, Mukherjee S (2013) Isotopes and ion chemistry to identify salinization of coastal aquifers of Sabarmati River Basin. Curr Sci 104(3):335-344

106. Dabral S, Sharma N (2014) A Hydro-Geochemical Evaluation of Groundwater Suitability for irrigation and domestic purposes: a case study from Narmada Mahi inter-stream region of Gujarat, India. ICHE, Hamburg - Lehfeldt \& Kopmann (eds), pp 321-326

107. Maurya P, Kumari R, Mukherjee $S$ (2019) Hydrochemistry in integration with Stable Isotopes $\left(\delta^{18} \mathrm{O}\right.$ and $\left.\delta \mathrm{D}\right)$ to assess Seawater intrusion in coastal aquifers of Kachchh district, Gujarat, India. J Geochem Explor 196:42-56. https://doi.org/10.1016/j.gexpl o.2018.09.013

108. Pujari PR, Soni AK (2009) Sea water intrusion studies near Kovaya limestone mine, Saurashtra coast, India. Environ Monit Assess 154:93-109

109. Singh AP, Gupta PK, Khandelwal M (2013) Prediction of sea water intrusion for mining activity in close precincts of sea shore. SpringerPlus. 2(417):1-10

110. Singh AP, Gupta PK, Khandelwal M (2015) Geophysical characterization of salinity ingress in Surka Mining Lease Area of Gujarat, India. J Powder Metall Min 4(2):1-6

111. Pateliya P, Singh NP, Mahmood K, Prakash I (2016) Impact of seawater intrusion on coastal aquifer of Bhavnagar, Gujarat, India using GALDIT method. Int J Adv Res Eng Sci Technol 3(5):477-484

112. Priyanka BN, Mohan KMS (2017) Direct and inverse modeling of seawater intrusion: a perspective. J Geol Soc India 90:595-601. https://doi.org/10.1007/s12594-017-0757-x

113. Gopinath S, Srinivasamoorthy K, Saravanan K, Prakash R (2018) Discriminating groundwater salinization processes in coastal aquifers of southeastern India: geophysical, hydrogeochemical and numerical modeling approach. Environ Dev Sustain 21:2443-2458. https://doi.org/10.1007/s10668-018-0143-x

114. Shoba S, Niranjan PS, Reddy M (2010) Application of groundwater model in coastal aquifer: a case study of Veraval area of Gujarat. Current World Environ 5(1):91-97

115. Kale GD, Samtani BK, Patel SB, Patel H, Anajwala NJ, Shah BH, Chaudhary P, Patel RA (2012) Modelling of sea water intrusion with Hele-Shaw model: a case study around Surat City, Gujarat. ISH J Hydraul Eng 18(3):215-223

116. Shah N, Pathak Y, Chudasama M (2015) Assessing temporal and spatial changes of salinity by inverse distance weighted modeling in ArcGIS. IJSRD Int J Sci Res Dev 3(02):1806-1809 
117. CSPC (Coastal Salinity Prevention Cell) (2007) Report. Ahmedabad, Gujarat

118. Darwish T, Atallah T, El Moujabber M, Khatib N (2005) Salinity evolution and crop response to secondary soil salinity in two agro-climatic zones in Lebanon. Agric Water Manag 78:152-164

119. Gururaja Rao G, Chinchmaltpure AR, Sanjay A, Khandelwal MK, Sharma DK (2013) Coastal saline soils of Gujarat: problems and their management. Technical Bulletin 1/2013, CSSRI, RRS, Bharuch

120. Allow AK (2012) The use of injection wells and a subsurface barrier in the prevention of seawater intrusion: a modelling approach. Arab J Geosci 5:1151-1161. https://doi.org/10.1007/ s12517-011-0304-9

121. Strack ODL, Stoeckl L et al (2016) Reduction of saltwater intrusion by modifying hydraulic conductivity. Water Resour Res 52:6978-6988

122. Abdoulhalik A, Ahmed A, Hamill GA (2017) A new physical barrier system for seawater intrusion control. J Hydrol 549:416-427

123. Hanson G, Nilsson A (1986) Ground-water dams for rural-water supplies in developing countries. Ground Water 24(4):497-506
124. Bruington $A E$ (1972) Saltwater intrusion into aquifers. JAWRA J Am Water Resour Assoc 8:150-160

125. Eslamian S (2014) Handbook of engineering hydrology. CRC Press, Boca Raton

126. Lee HJ, Normark WR (2009) Earth science in the urban ocean: the Southern California Continental Borderland, Boulder, Colorado. Geol. Soc. of Am, Boulder

127. Dhakate R, Sankaran S, Kumar VS, Amarender B, Harikumar $P$, Subramanian SK (2016) Demarcating saline water intrusion pathways using remote sensing, GIS and geophysical techniques in structurally controlled coastal aquifers in Southern India. Environ Earth Sci 75(363):1-19. https://doi.org/10.1007/ s12665-015-4940-3

Publisher's Note Springer Nature remains neutral with regard to jurisdictional claims in published maps and institutional affiliations. 